\title{
Thermal characterization of Partially Hydrolyzed Cassava (Manihot esculenta) Starch Granules
}

\author{
Luiz Gustavo Lacerda ${ }^{1}$, Jayme Augusto Menegassi Azevedo ${ }^{1}$, Marco Aurélio da Silva \\ Carvalho Filho $^{2}$, Ivo Mottin Demiate ${ }^{3}$, Egon Schnitzler ${ }^{3}$, Luciana Porto de Souza \\ Vandenberghe $^{1}$ and Carlos Ricardo Soccol ${ }^{1 *}$ \\ ${ }^{1}$ Divisão de Engenharia de Bioprocessos e Biotecnologia; Universidade Federal do Paraná; C. P.: 19011; \\ soccol@ufpr.br; 81531-990; Curitiba - PR - Brasil. ${ }^{2}$ Departamento de Pesquisa; Centro Universitário Positivo; \\ Av. Prof. Pedro Viriato Parigot de Souza, 5300; 81280-330; Curitiba - PR - Brasil. ${ }^{3}$ Departamento. de Engenharia \\ de Alimentos; Universidade Estadual de Ponta Grossa;; Av. Carlos Cavalcanti, 4748; 84030-900; Ponta-Grossa - \\ PR - Brasil
}

\begin{abstract}
Cassava starch, partially hydrolyzed by fungal $\alpha$-amylase, was characterized using thermal analysis, light microscopy and X-ray diffraction. Thermal degradation was initiated at lower degradation temperatures after enzymatic treatment and the DSC (Differential scanning calorimetry) analysis showed almost similar range of gelatinization temperature, but the enthalpies of gelatinization were quite increased for the partially hydrolyzed starch granules. The results suggested that the partial degradation of the starch granules was concentrated in the amorphous regions.
\end{abstract}

Keywords: amylase, cassava, hydrolysis, thermal analysis.

\section{INTRODUCTION}

Starch is the most important storage reserve of carbohydrates in plants. Many of the starch-storing organs are staple foodstuffs in the human diet (Cereda and Vilpoux, 2003). Cassava ranks very high among crops that convert the greatest amount of solar energy into soluble carbohydrates per unit of area. Among the starchy staples, cassava gives a carbohydrate production which is about $40 \%$ higher than rice and $25 \%$ superior to corn, with the result that cassava is the cheapest source of calories for both human nutrition and animal feeding. Typical composition of cassava root is moisture $(70 \%)$, starch $(24 \%)$, fiber $(2 \%)$, protein $(1 \%)$ and other substances including minerals (3\%) (Tokuari, 2004). Starch transformations can be made by chemical, microbiological and/or enzymatic hydrolysis.

The starch hydrolysis, catalyzed by $\alpha$-amylase, is on of the most important large scale practice 'regarding enzymatic processes (Konsula and Kyrikiades, 2003). The fact that some enzymes have the particular capacity to convert starch in shorter polymers of glucose units, has made it subject of several studies in the past years for the use of this kind of process (Kandra, 2003; Li et al, 2004). In fact, traditional acid hydrolysis of starch

Author for correspondence 
to glucose is being superseded by enzymatic processes (Pandey et al., 2000). This is due to the reason that acid processes leads to undesirable byproducts.

The bakery industry, for instance, is a great consumer of both starches and enzymes. Only in the USA, there is a loss of more than U\$ 1 billion/year due to the problem of bread staling. Besides, generating fermentable compounds, fungal $\alpha$ - amylase also has an anti-staling effect in baking and they improve the softness retention of baked goods (Gupta et al., 2003; Van der Maarel et al., 2002).

Cassava wastes have high amounts of starchy material, thus it can be a potential source for bioethanol production (Leonel and Cereda, 1999).

Thermal analysis is a general name for a group of analytical techniques used to monitor the behavior of a material as a function of temperature or time at a specific temperature (Ionashiro, 2005). Differential scanning calorimetry (DSC) is used to determine the temperature and enthalpy of a phase transformation. For more than 20 years DSC has been widely used for the study of the starch gelatinization, a physical transformation that occurs when starch-water slurry is submitted to a heating process (Cereda and Vilpoux, 2003; Van der Maarel et al., 2002; Ionashiro, 2005).

In thermogravimetry (TG) analysis, the exact mass of a sample is determined while it undergoes a temperature treatment. TG can help to show the starch granules behavior when heated, leading to depolymerization (Cereda and Vilpoux, 2003; Aggarwal and Dollimore, 1998). In order to analyze the enzymatic action on the granules, light microscopy was used to show how the enzyme acts on the granules (Cereda and Vilpoux, 2003, Li et al, 2004; Aggarwal and Dollimore, 1998). The rate of hydrolysis of starch granules strongly depends upon the botanical source from which they are obtained. This study was performed to obtain a better understanding (knowledge) of the effect of hydrolysis by the action of fungal $\alpha$ amylase on granular cassava starch.

\section{MATERIAL AND METHODS}

\section{Material}

Commercial grade regular cassava starch $\left(\right.$ Yoki $^{\circledR}$, Brazil) was acquired from a local supermarket. Food grade fungal $\alpha$-amylase (E.C. 3.2.1.1) 4000 SKB (SKB unit per gram is defined as number of grams of dextrinized soluble starch, in the presence of enzyme per hour under $40{ }^{\circ} \mathrm{C}$ and $\mathrm{pH}$ 5.0) from Aspergillus oryzae, named Spring Alfa, specially produced for baking processes was purchased from Granotec (Curitiba PR, Brazil).

\section{Hydrolysis}

Samples were identified by hydrolysis time (i. e. one, two or three hours). For $3.0 \mathrm{~g}$ of cassava starch, $8.0 \mathrm{~mL}$ of distilled water were added and $\mathrm{pH}$ was adjusted to 5.0 by adding $0.1 \mathrm{~mol}^{-\mathrm{L}^{-1}}$ hydrochloric acid solution. The samples were placed on a water bath at $40{ }^{\circ} \mathrm{C}$ under continuous stirring and $15.0 \mathrm{mg}$ of the enzyme preparation was added to each sample. After each hour, up to three hours, samples were removed from the water bath and the $\mathrm{pH}$ was adjusted to 2.0 with the same hydrochloric acid solution in order to stop the enzyme reaction. The samples were centrifuged at $3200 \mathrm{rpm}$ during 6 minutes and the supernatant was stored in a freezer. Solid samples were removed and dried in a vacuum oven at room temperature, then kept in a desiccator over anhydrous calcium chloride.

\section{Thermal Analysis}

Thermal analysis TG, DTA, DTG and DSC curves were recorded using a SHIMADZU TG 60 and DSC 60, with synthetic air flowing at 100 $\mathrm{mL} \cdot \mathrm{min}^{1}$, and a heating rate of $10{ }^{\circ} \mathrm{C} \cdot \mathrm{min}^{-1}$ and with samples mass about $5 \mathrm{mg}$. Alumina open sample holder and aluminum sealed crucibles were used for TG/DTG and DSC respectively. TG is used to measure the mass loss either as a function of time (isothermal) or dynamic temperature and controlled atmosphere (Mothé et al., 2006). DSC studies were carried out in order to study the gelatinization event. A 4:1 (water:starch) mixture was prepared and left overnight in order to equilibrate moisture content.

\section{Microscopy \\ Microscopy analysis was carried out using a stereoscopic microscope (Olympus SZX9), polarizing filter and camera (Cybernetic's Cool Snap Pro Color). The photographs were identified and scaled using Image Pro Plus and the images were sized to $1000 \mathrm{X}$.}

\section{X-ray diffraction}

$\mathrm{X}$-ray powder patterns were obtained by using a Siemens D-5000 X-Ray diffractometer, with 
$\mathrm{CuK} \alpha$ radiation $(\lambda=1,544 \AA)$ and a setting of $40 \mathrm{kV}$ and $20 \mathrm{~mA}$.

\section{RESULTS AND DISCUSSIONS}

\section{Thermal analysis}

Table 1 shows cassava starch degradation results during hydrolysis. According to literature (Aggarwal and Dollimore, 1998), the thermal treatment in starches normally leads to its depolymerization when the applied temperature exceeds $300^{\circ} \mathrm{C}$. The starch passes through a series of irreversible alterations: at a first moment the structural alteration takes polymer to the formation of pyrodextrins. At higher temperatures, the macro-molecules depolymerization leads to the formation of levoluglucosan, furfural, volatile products of lower molecular weight and, at last, carbon products.

Thermogravimetry also allows evaluating water content in the sample. Soliman et al. (1997) used the limit of $150{ }^{\circ} \mathrm{C}$ for such evaluation. It was observed that the loss of moisture and other easily volatile materials and the posterior loss of mass of the samples had a variation of approximately $2 \%$. Starch thermal stability results found in the present study are shown in Figure 1, which are in agreement with those of other researchers (Aggarwal and Dollimore, 1998). The on-set (graphic tangent) temperatures decreased during observations (Table1). This was probably due to the fact that enzyme activity leads to a higher available surface area to heating process, hence the pyrolysis process started at lower temperatures.

Table 1 - Thermal degradation results of cassava starch granules (untreated state and during hydrolysis process).

\begin{tabular}{ccccc}
\hline Cassava starch & untreated & $\mathbf{1 h}$ & $\mathbf{2 h}$ & $\mathbf{3 h}$ \\
\hline Moisture $(\%)$ & 9.88 & 11.03 & 8.55 & 10.89 \\
Mass loss $(\%)$ & 97.33 & 98.63 & 97.86 & 98.23 \\
On-set $\left({ }^{\circ} \mathrm{C}\right)$ & 300.55 & 300.68 & 297.60 & 295.76 \\
DTG peak $\left({ }^{\circ} \mathrm{C}\right)$ & 317.65 & 314.08 & 311.76 & 300.82 \\
\hline
\end{tabular}
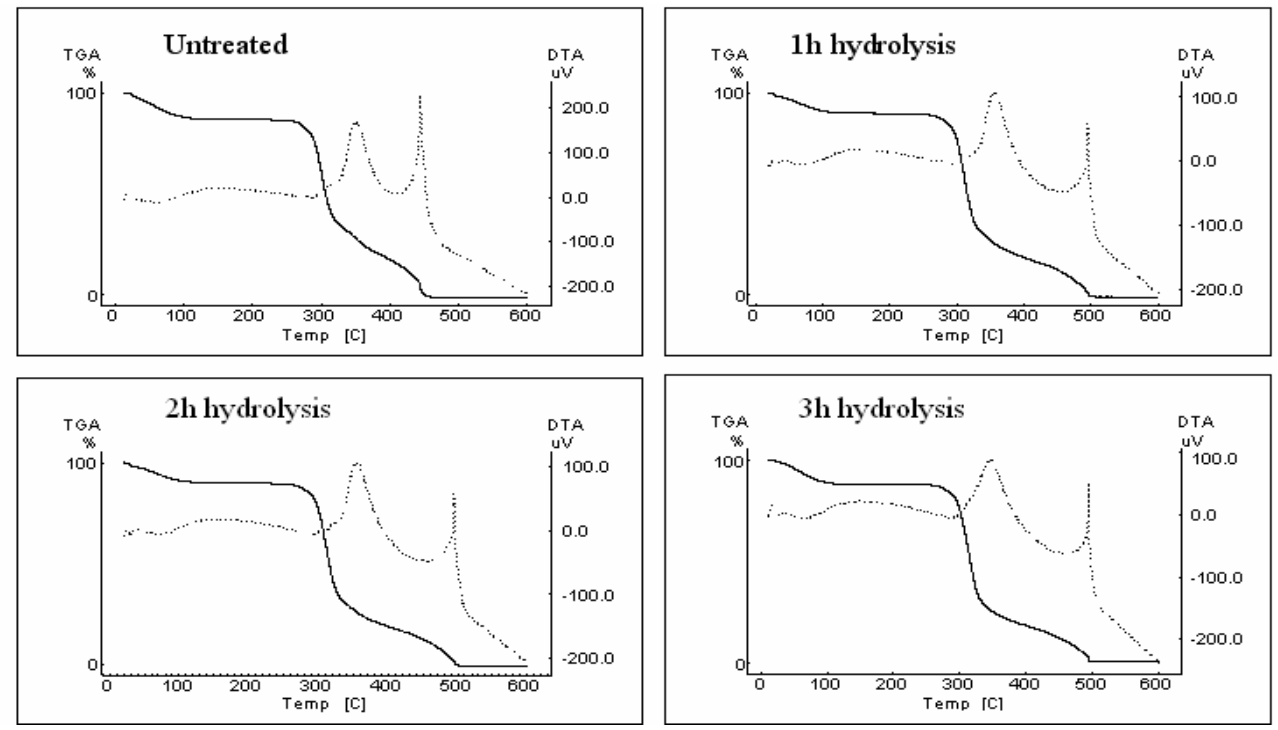

Figure 1 - TG and DTA curves of cassava starch granules (untreated state and during hydrolysis process). 
These results were observed also in another structural change study using oxidation treatment (data not shown). Also in Figure 1, Differential Thermal Analysis (DTA) is an analytical method in which the sample and an inert reference material are heated concurrently, each having its own temperature sensing and recording apparatus (Ionashiro, 2005). All TG curves were recorded using synthetic air. Thus, DTA showed two degradation peaks: probably at lower temperatures, related to initial starch mass loss and the second related to the organic material oxidation.
Derivative thermogravimetry (DTG) is a math method that indicates with exactness, the corresponding temperatures to the beginning and the instant where the reaction speed is maximum (Ionashiro, 2005).

DTG results illustrated in Figure 2 and Table 1 indicated the respective peaks difference of the raw state to the end of enzyme treatment. Other researchers (Mothé et al., 2006) had also got difference in such result, however, using another enzyme and giving more time for its action, they observed a bigger difference.

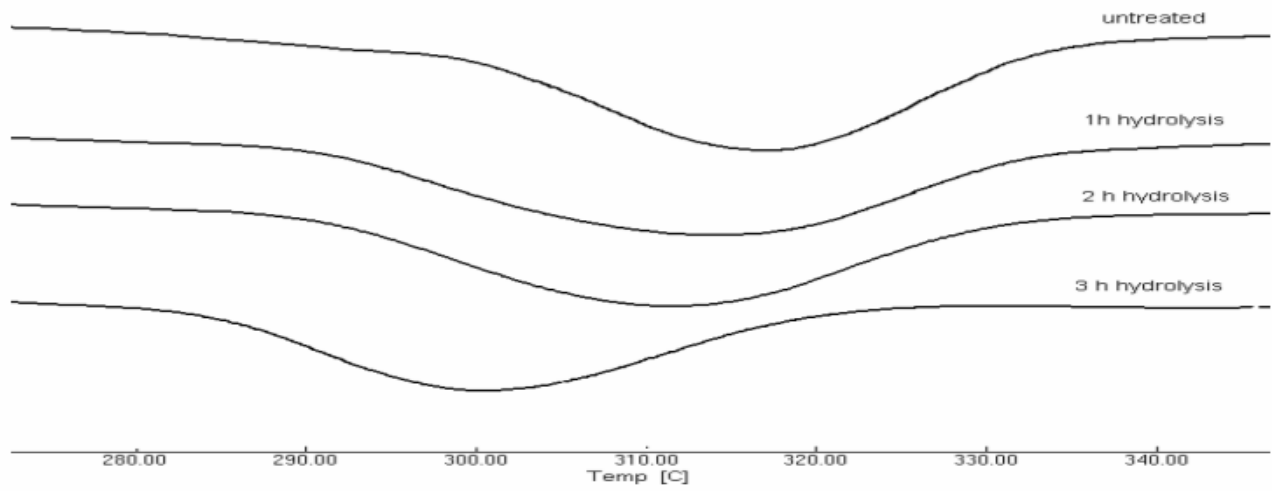

Figure 2 - DTG results of cassava starch granules (untreated state and during hydrolysis process).

The energy required for the molecular order disrupture differs in the same botanical source, thus, the gelatinization occurs in a temperature range (Cereda and Vilpoux, 2003). As shown by the DSC analysis in Table 2, the range of gelatinization temperature had a variation of less than $1^{\circ} \mathrm{C}$ between the samples of same botanical origin.

The increasing of enthalpy required to the process (Fig. 3), suggested an increasing of crystalline characteristic of the material.
The crystallinity of starch is associated with the amylopectin presence (Yu and Christie, 2001; Zhang and Hamaker, 2006) that probably did not suffer the same intensity of the enzymatic attack as occurred in the amorphous region normally associated to amylose. The amylose content in regular cassava native starch could vary between 17 and $24 \%$ (Defloor et al., 1998).

Table 2 - DSC results of cassava starch granules (untreated state and during hydrolysis process).

\begin{tabular}{ccccc}
\hline Cassava starch & untreated & 1h & 2h & 3h \\
\hline On-set $\left({ }^{\circ} \mathrm{C}\right)$ & 57.92 & 56.81 & 56.97 & 58.84 \\
Peak $\left({ }^{\circ} \mathrm{C}\right)$ & 63.43 & 62.84 & 62.67 & 62.64 \\
$\Delta \mathrm{H}(\mathrm{J} / \mathrm{g})$ & 12.89 & 13.44 & 13.18 & 23.62 \\
\hline
\end{tabular}




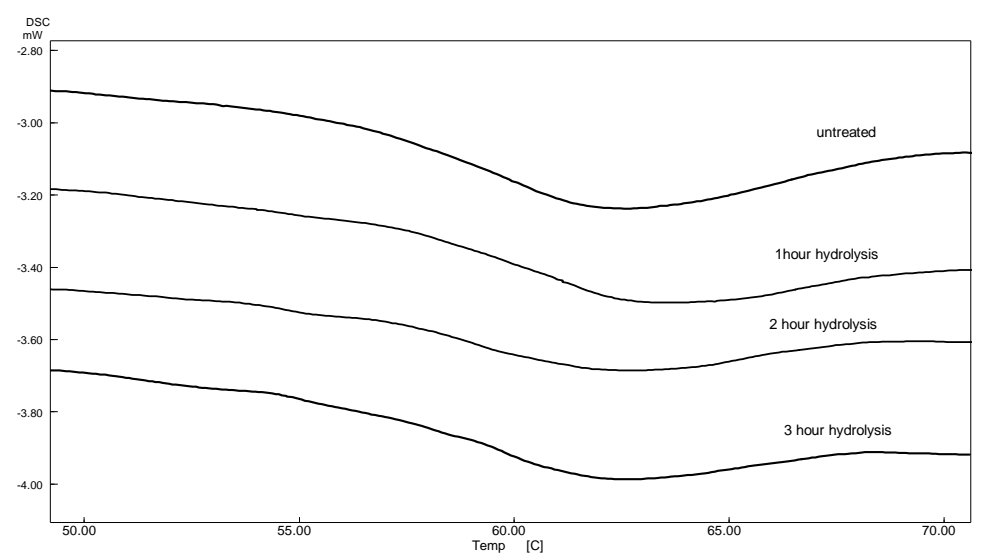

Figure 3 - DSC curves of starch/water samples.

\section{Microscopy}

Native and treated starch granules of cassava observed in Figure 4 showed differences in form and size. Cassava normally presented regular morphology confirming what was previously observed by other researchers (Cereda and Vilpoux, 2003).

During the time of enzymatic action, gradually the granules suffered morphological alterations.

The microscopy study of the morphological alteration of the granules was made with glucoamylase in different starches. This phenomenon was also observed by other researchers (Zhang and Hamaker, 2006; Ma et al., 2006; Sarikaya et al., 2000) during enzymatic treatment with other amylases in native granules of different botanical sources.

Enzymes have preference to attack in a first moment irregularities on starch surface. This observation could explain the fact that treated material had affected areas due to the enzyme action.

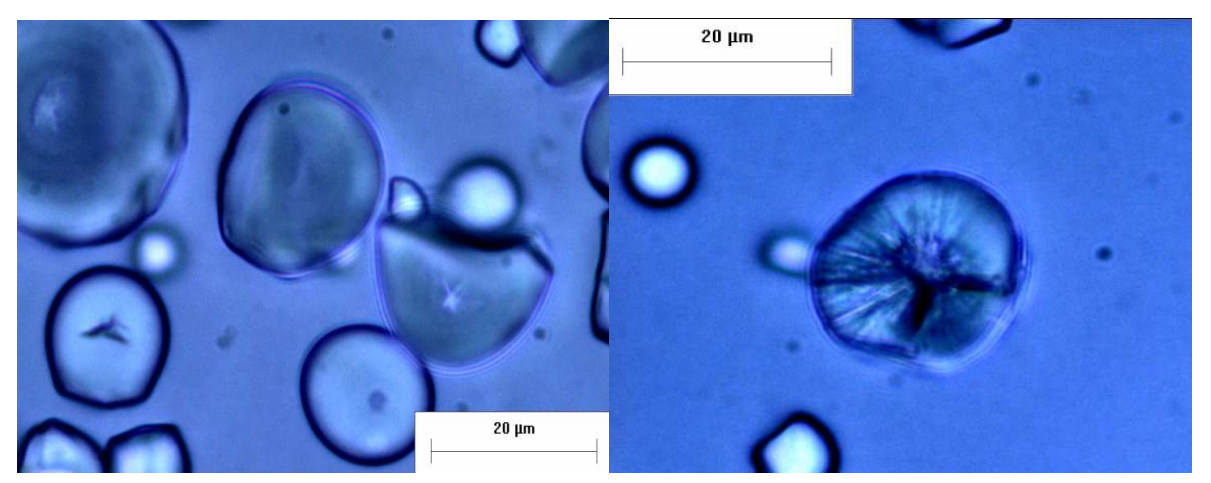

Figure 4 - Pictures sized to 1000X of untreated cassava sample and after 3 h hydrolysis.

\section{X-ray diffraction}

Starches tend to present particular crystalline arrangements regarding their botanical origin. The intensity of few diffraction peaks can suggest different crystallinity patterns (Cereda and
Vilpoux, 2003). For cereal or A pattern, these peaks appear predominantly as one doublet at $18^{\circ}(2 \theta)$ and a singlet at $23^{\circ}(2 \theta)$.

Tubers or B pattern are recognized by the intensity of the corresponding band to one doublet at $5^{\circ}(2 \theta)$ 
and $6^{\circ}(2 \theta)$, two singlets at $15^{\circ}(2 \theta)$ and $17^{\circ}(2 \theta)$ and one doublet at $22^{\circ}(2 \theta)$ and $24^{\circ}(2 \theta)$. X-ray diffraction patterns of cassava starch are shown in Figure 5. It was possible to observe the major

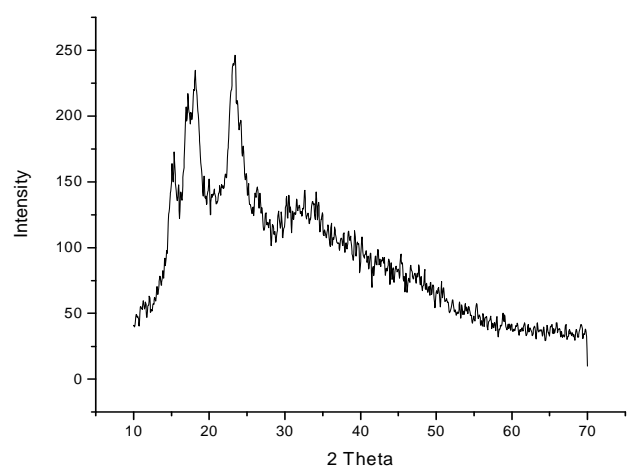

peaks intensities modifications. In addition, after three hours, there was a more evidentiated doublet at $22^{\circ}(2 \theta)$, suggesting a tuber pattern after the treatment.

Figure 5 - X-ray patterns of native cassava starch and after three hours under treatment

Aggarwall and Dollimore (1998) studied the cristallinity of several starches under enzymatic treatment. However, they did not study cassava starch. During their study, the characteristic patterns were more evident for original botanic sources after hydrolysis.

\section{CONCLUSIONS}

Microscopic studies assisted to understand that the enzyme acted initially on granules surface and especially in their irregularities. Thermogravimetry helped to observe starch hygroscopicity, thermal stability of raw state and how it decreased during hydrolysis due to the higher surface area.

DSC had illustrated, with precision, a particular structural changing event of great importance for the industry: the starch gelatinization. DSC results showed that the peaks did not suffer displacement in comparison with the raw state and during the hydrolysis advance. However, the increasing of enthalpy required to the process evidentiates higher percentages of material with crystalline characteristic at the end of the observations. The $\mathrm{X}$-ray diffraction showed a tuber pattern after three hours under hydrolysis.

\section{ACKNOWLEDGEMENTS}

This research is dedicated in memory of David Dollimore.

\section{RESUMO}

Amilases fúngicas são comumente empregadas a amidos com o intuito de otimizar o rendimento de leveduras, modificar a textura de produtos panificados e prolongar a vida de prateleira do produto final. A hidrólise parcial enzimática pode auxiliar no entendimento da estrutura do amido ganular. Amido de mandioca parcialmente hidrolisado por $\alpha$-amilase fúngica foi investigado utilizando-se técnicas termoanalíticas, microscopia ótica e difratometria por raios X. A degradação térmica iniciou-se a temperaturas menores após o tratamento enzimático e a análise por DSC mostrou uma próxima faixa de temperatura de gelatinização, porém, a entalpia necessária para o evento foi maior para os grânulos parcialmente hidrolisados. Os resultados sugerem que a degradação parcial do amido granular foi concentrada em regiões amorfas. 


\section{REFERENCES}

Aggarwall, P. and Dollimore, D. (1998), A thermal analysis investigation of partially hydrolyzed starch. Thermochimica Acta, 319, 17-25.

Cereda, M. P. and Vilpoux, O. (2003), Tecnologia, Usos e Potencialidades de Tuberosas Amiláceas Latino Americanas. Fundação Cargill, São Paulo.

Defloor, I; Dehing, I.; Delcour, J. A. (1998), Physicochemical properties of cassava starch. Stärke, 50, 5864.

Gupta, R., Gigras, P., Mohapatra, H., Goswami, V. K., and Chauhan, B. (2003). Microbial a-amylase: a biotechnological perspective. Process Biochemistry, 38, 1599-1616.

Ionashiro, M. (2005), “Giolito" Fundamentos de Termogravimetria e Análise térmica Diferencial/Calorimetria Exploratória Diferencial, Giz, SaoPaulo.

Jobling, S. (2004), Improving starch for food and industrial applications. Plant Biotechnology, 7, $210-$ 218.

Kandra, L.(2003), $\alpha$-Amilases of medical and industrial importance. J. of Mol. Struct. :Theochem,487, 666667.

Konsula, Z., and Liakopoulou-Kyriakides, M. (2004). Hydrolysis of starches by the action of an a-amylase from Bacillus subtilis. Process Biochemistry, 39, 1745-1749.

Leonel, M.; Cereda, M. P. (1999), Avaliação da celulase e pectinase como enzimas complementares, no processo de hidrólise-sacarificação do farelo de mandioca para produção de etanol. Ciênc. Tecnol. Aliment., 19, 113 - 117.

Li, J; Vasanthan, T.; Hoover, R; Rossnagel, B. (2004), Starch from hull-less barley: V. In vitro susceptibility of waxy, normal and high amylose starches towards hydrolysis by alpha-amylases and amyloglucosidase. Food Chemistry, 84, p.621-632.

Ma, Y.;Cai, C.; Wang, J.; Sun, D. W. (2006), Enzymatic hydrolysis of corn starch for producing fat mimetics Journal of Food Engineering, 73, 297-303.
Mothé , C. G.; Correia, D. Z.; França, F. P. ; Riga, A. T. (2006), Thermal and rheological study of polysaccharides for enhanced oil recovery . J. Therm. Anal. Cal., 85, 31-36.

Pandey, A., Nigam, P., Soccol, C. R., Soccol, V. T., Sing, D., and Mohan, R. (2000). Advances in microbial amylases. Biotechnology and Applied Biochemistry, 31, 135-152.

Sarikaya, E.; Higasa, T.; Adachi, M.; Mikami, B. (2000), Comparison of degradation of $\alpha$ - and $\beta$ amylases on raw starch granules. Process Biochemistry, 35, 711-715.

Soliman, A.; EL-Shinnavy, N. A.; Morabak , F. (1997), Thermal behaviour of starch and oxidized starch. Thermochimica Acta, 296, 149-153.

Tonukari, N. J. (2004), Cassava and the future of starch, Electronic Journal of Biotechnology , 7, available on line http://www.ejbiotechnology.info/content/vol7/issue1 /issues/2/

Van der Maarel, M.J.E.C.; van der Veen, B.; Uitdehaag, J.C.M.; Leemhuis, H.; Dijkhuizen, L. (2002), Properties and applications of starch-converting enzymes of the $\alpha$-amylase family. Journal of Biotechnology, 94, 137 - 155.

Yu, L. and Christie, G. (2001), Measurement of thermal transitions using differential scanning calorimetry. Carbohydrate Polymers, 46, 179-184.

Zhang, G.; Ao, Z.; Hamaker B. R. (2006), Structural basis for the slow digestion property of native cereal starches, Biomacromolecules, 7 , 3259 - 32 .

Received: September 26, 2007; Revised: July 29, 2008; Accepted: October 10, 2008 
PAGINA

EM

BRANCO 